\title{
SURGICAL TREATMENT OF FAMILIAL ADENOMATOUS POLYPOSIS: ileoretal anastomosis or restorative proctolectomy?
}

\author{
Fábio Guilherme CAMPOS'1, Rodrigo Oliva PEREZ1', Antônio Rocco IMPERIALE'1, \\ Víctor Edmond SEID', Sérgio Carlos NAHAS', Ivan CECCONELLO²
}

\begin{abstract}
Context - Controversy regarding the best operative choice for familial adenomatous polyposis lays between the morbidity of restorative proctocolectomy and the supposed mortality due to rectal cancer after ileorectal anastomosis. Objectives -To evaluate operative complications and oncological outcome after ileorectal anastomosis and restorative proctocolectomy. Methods - Charts from patients treated between 1977 and 2006 were retrospectively analyzed. Clinical and endoscopic data, results of treatment, pathological reports and information regarding early and late outcome were recorded. Results - Eighty-eight patients - 41 men (46.6\%) and 47 women $(53.4 \%)$ - were assisted. At diagnosis, 53 patients (60.2\%) already had associated colorectal cancer. Operative complications occurred in 25 patients $(29.0 \%)$, being $17(19.7 \%)$ early and $8(9.3 \%)$ late complications. There were more complications after restorative proctocolectomy $(48.1 \%)$ compared to proctocolectomy with ileostomy $(26.6 \%)$ and ileorectal anastomosis $(19.0 \%)(P=$ $0,03)$. There was no operative mortality. During the follow-up of 36 ileorectal anastomosis, cancer developed in the rectal cuff in six patients $(16,6 \%)$. Cumulative cancer risk after ileorectal anastomosis was $17.2 \%$ at 5 years, $24.1 \%$ at 10 years and $43.1 \%$ at 15 years of follow-up. Age-dependent cumulative risk started at 30 years (4.3\%), went to $9.6 \%$ at 40 years, $20.9 \%$ at 40 years and $52 \%$ at 60 years. Among the 26 patients followed after restorative proctocolectomy, it was found cancer in the ileal pouch in $1(3.8 \%)$. Conclusions - 1 . Operative complications occurred in about one third of the patients, being more frequently after the confection of ileal reservoir; 2. greater age and previous colonic carcinoma were associated with the development of rectal cancer after ileorectal anastomosis; 3 . patients treated by restorative proctocolectomy are not free from the risk of pouch degeneration; 4. the disease complexity and the various risk factors (clinical, endoscopic, genetic) indicate that the best choice for operative treatment should be based on individual features discussed by a specialist; 5 . all patients require continuous and long-term surveillance during postoperative follow-up.

HEADINGS - Adenomatous polyposis coli. Adenomatous polyps. Colorectal neoplasms. Proctocolectomy, restorative. Anastomosis, surgical.
\end{abstract}

\section{INTRODUCTION}

The various polyposis syndromes (PS) may differ in number, distribution and histological nature of the polyps. Within the intestinal tract, PS are responsible for $2 \%$ of all colorectal malignant tumors, the basic lesion being an adenoma (familial adenomatous polyposis, attenuated familial adenomatous polyposis, Gardner syndrome, Turcot syndrome) or hamartoma (Peutz-Jeghers syndrome, juvenile polyposis, Cowden syndrome, Bannayan-Riley-Ruvalacaba syndrome and Cronkhite-Canada syndrome) $)^{(7,8)}$.

Familial adenomatous polyposis (FAP) accounts for approximately $1 \%$ of colorectal cancer cases ${ }^{(13)}$. The classical syndrome is an autosomic hereditary disease caused by a germinative mutation in the APC gene (adenomatous polyposis coli), located on the long arm of chromosome 5q21, which confers a dominant character to the syndrome, although $20 \%$ of patients do not exhibit familiar history $(5,10,11,22)$.

Surgical treatment options include proctocolectomy and terminal ileostomy (PCI), total colectomy and ileorectal anastomosis (IRA) and restorative proctocolectomy (RPC) with pouch anal anastomosis. In each patient, the best option should be based on parameters such as age, local and number of polyps, genetic mutation locus and acceptance of the patient to undergo long-term follow-up ${ }^{(9)}$.

There are still many controversies regarding the best prophylactic operation for FAP. PCI may lead to profound body image and emotional alterations related to the stoma and sexual dysfunction. Thus, its

Colorectal Service, "Hospital das Clínicas", Gastroenterology Department, University of São Paulo Medical School.

${ }^{1}$ Colorectal Service, "Hospital das Clínicas, Faculdade de Medicina da Universidade de São Paulo"; ${ }^{2}$ Divisions of Digestive System Surgery and Coloproctology, São Paulo University Medical School, São Paulo, SP, Brazil.

Correspondence: Prof. Fábio Guilherme Campos - Rua Pe. João Manoel, 222 - Cj.120 - 01411-000 - São Paulo, SP, Brazil. E-mail: fgmcampos@terra.com.br 
indication has been limited to polyposis patients associated with low rectal cancer or sphincteric disorders.

The most commonly indicated procedures are IRA and RPC. Since its introduction, RPC has suffered continuous modifications in order to achieve better functional outcome, less morbidity and mucosal disease control. Despite some controversies, RPC progressively turned out to be the gold standard treatment for FAP and ulcerative colitis ${ }^{(2)}$.

Although it was initially thought that this procedure would abolish the risk of adenomas in FAF patients, it has been documented the development of adenomas within the ileal pouch many years after the surgical treatment ${ }^{(38)}$. Furthermore, there is a risk of malignant transformation attested by some reports of cancer at the ileal pouch or at the ATZ ${ }^{(9,16)}$.

On the other hand, IRA provides good surgical and functional outcome ${ }^{(4)}$, but it is associated with an elevated risk of metachronous rectal cancer in rates varying from $12 \%$ to $43 \%$ in non-selected patients ${ }^{(36)}$.

Within this context, the aims of the present work were to evaluate the surgical complications and the oncological outcome of patients who underwent IRA or RPC, making an analysis of the risk factors that might be involved in each procedure.

\section{METHODS}

The population of this study is formed by FAP patients treated at the Coloproctology Unit (Gastroenterology Department) in "Hospital das Clínicas", University of São Paulo School of Medicine, São Paulo, SP, Brazil.

There were analyzed data from patients treated during the last 29 years (January 1977 and March 2006). Diagnosis was established through colonoscopic and histological exams of colorectal polyps. Data retrieved from patient charts were collected to organize clinical, endoscopic, histological and follow-up information (Figure 1).

Statistical analysis was developed using parametric tests ( $t$ Student) and non-parametric (Qui-square and Mann-Whitney). Rejection of nullity hypothesis was established at $0.05(5 \%)$.

\section{RESULTS}

There were evaluated data from 88 patients, being 41 men $(46,6 \%)$ and 47 women $(53,4 \%)$. At diagnosis, average age was 35.9 years (15 to 82$)$ and 53 patients $(60.2 \%)$ already had associated colorectal cancer (CRC) that was diagnosed by colonoscopy or histological exam.

Endoscopic characterization of the polyposis was obtained in 84 patients. Attenuated polyposis was found in 12 patients $(14.3 \%)$ and the others were classified as classical polyposis $(\mathrm{n}=72 ; 85.7 \%) ; 8$ of these patients presented a severe picture of the syndrome.

Among the 88 patients, 86 were operated on. Two patients $(2.3 \%)$ were not operated due to disseminated cancer or religious reasons. Operative procedures consisted of 15 total proctocolectomies with ileostomy (PCI), 27 RPC with ileal pouch, 42 total colectomies with IRA, 1 palliative segmentar resection and 1 intestinal deviation (internal bypass).

Figure 2 presents the percentages of each surgical procedure during five consecutive periods.

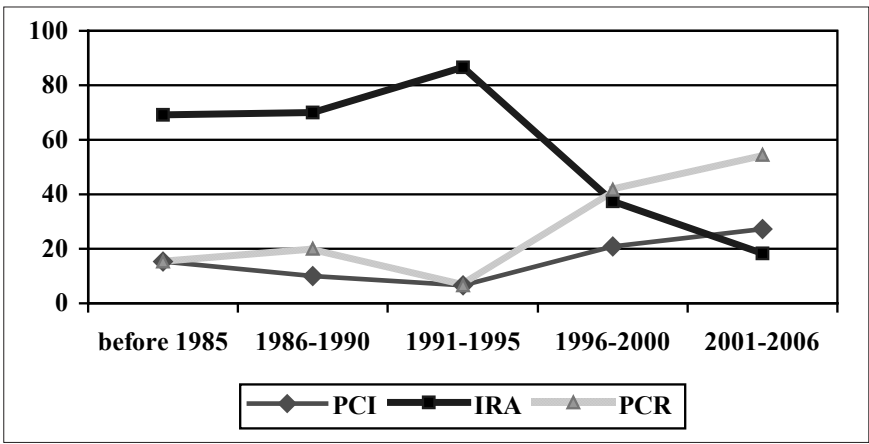

FIGURE 2. Percentual distribution of operative procedures performed in five consecutive periods

The incidence of early and late complications for each operative procedure is presented in Table 1 .

\begin{tabular}{|l|l|l|}
\hline Polyp features & Surgical treatment & Follow-up \\
\hline Colonic adenoma distribuition & Number of operated patients & Polyp recurrence in rectal cuff or ileal pouch \\
\hline rectal polyposis severity & Type of operative procedure & Tumoral recurrence (local, distant, rectal cuff and ileal pouch) \\
\hline Association polyposis - coloretal cancer & Early and late morbidity and mortality & Length of follow-up \\
\hline
\end{tabular}

FIGURE 1. Endoscopic, surgical and follow-up data

TABLE 1. Number and percentage of early and late complications in 86 patients

\begin{tabular}{|c|c|c|c|c|c|c|c|c|c|c|}
\hline \multirow{2}{*}{ Complications } & \multicolumn{2}{|c|}{ PCI (15) } & \multicolumn{2}{|c|}{ IRA (42) } & \multicolumn{2}{|c|}{ RPC (27) } & \multicolumn{2}{|c|}{ SR (1) } & \multicolumn{2}{|c|}{ ID (1) } \\
\hline & $\mathrm{n}$ & $\%$ & $\mathrm{n}$ & $\%$ & $\mathrm{n}$ & $\%$ & $\mathrm{n}$ & $\%$ & $\mathrm{n}$ & $\%$ \\
\hline Early & 1 & 6.6 & 7 & 16.6 & 9 & 33.3 & 0 & & 0 & \\
\hline Late & 3 & 20.0 & 1 & 2.4 & 4 & 14.8 & 0 & & 0 & \\
\hline Subtotal & 4 & 26.6 & 8 & 19.0 & 13 & 48.1 & 0 & & 0 & \\
\hline Total & 25 & 29.0 & & & & $\begin{array}{l}\text { ii-squa } \\
\text { PCI; }\end{array}$ & $\begin{array}{l}0.0 \\
\text { PC }\end{array}$ & & & \\
\hline
\end{tabular}


Table 2 shows that complications were registered in 25 patients $(29.0 \%)$, being $17(19.7 \%)$ early and $8(9.3 \%)$ late (after 30th postoperative day). Statistical analysis showed that RPC rates $(48.1 \%)$ were greater than PCI $(26.6 \%)[P=$ $0.005]$ and IRA $(19.0 \%)[P=0.001]$ There was no difference between PCI and IRA $(P=0.5)$.

TABLE 2. Patients treated with polypectomy after ileorectal anastomosis or restorative proctocolectomy and incidence of cancer in the rectal cuff and ileal pouch

\begin{tabular}{lcccc}
\hline Procedure & $\begin{array}{c}\text { Polyps } \\
\text { recurrence }\end{array}$ & Per cent & $\begin{array}{c}\text { Cancer } \\
\text { recurrence }\end{array}$ & Per cent \\
\hline IRA ( $\mathrm{n}=42)$ & 26 & $72,2 \%$ & 6 & $16,6 \%$ \\
RPC $(\mathrm{n}=27)$ & 3 & $11,5 \%$ & 1 & $3,8 \%$ \\
\hline IRA = total colectomy with ileorectal anastomosis; $\mathrm{RPC}=$ restorative proctocolectomy.
\end{tabular}

Early complications were more frequent in IRA patients $(16.6 \%)$ when compared to those who underwent PCI $(6.6 \%)$. Otherwise, when analyzing late complications there is an inversion of values, as PCI rates were greater $(20 \%)$, when compared to RPC $(14.8 \%)$ and IRA $(2.4 \%)$.

There was no mortality in the present series. During followup, reoperation was required in two IRA patients $(4.8 \%)$, in two RPC (7.4\%) and in one PCI (6.6\%).

Among the 80 patients that had undergone curative resection, local or distant recurrences were detected in $6(7.5 \%)$ during follow-up. These patients comprise $11.3 \%$ of those 53 who had colorectal cancer associated with the polyposis.

The occurrence of polyps and cancer after IRA and $\mathrm{RPC}$ is shown in Table 2. In relation to the original number of patients of each group, there were followed $80 \%$ of PCI (12), $85.8 \%$ of IRA (36) and $96.3 \%$ that had undergone RPC (26). Table 3 presents the main clinical features of patients who had tumoral recurrence in rectal cuff.

There was estimated the risk of rectal cancer after performing IRA (Kaplan-Meier method). The cumulative risk of rectal cancer after IRA was $17.2 \%$ after 5 years, $24.1 \%$ after 10 years and $43.1 \%$ after 15 years of follow-up. And the cumulative risk age-dependent starts at 30 years $(4.3 \%)$, going to $9.6 \%$ at 40 years, $20.9 \%$ at 40 years and $52 \%$ at 60 years.

Among the patients who underwent RPC that were followed (26), only $1(3.8 \%)$ developed cancer at the ileal pouch, 12 years after the initial operation. This patient had 40 years when underwent surgery, and the histological evaluation showed an associated colonic cancer. He was managed with pouch resection and definitive ileostomy; the pathologist found a $\mathrm{T} 2 \mathrm{~N} 0$ adenocarcinoma and multiple microadenomas at the ileal pouch.

\section{DISCUSSION}

The most important clinical feature of FAP is the almost inevitable adenoma degeneration, expressed by the virtual $100 \%$ penetrance in non-treated patients. In FAP patients diagnosed out of screening programs, the incidence of $\mathrm{CRC}$ is greater than $60 \%{ }^{(15)}$. In the present work, we found associated CRC in $60.2 \%$ and patient's average age was 35.9 years, similar to other series ${ }^{(17)}$. This is due to the fact that most of them were not diagnosed after their symptoms, not on the basis of family history.

Despite the introduction of technical procedures, a better selection process and the development of molecular biology during the last decades, the choice for the best operation in FAP patients still demand much debate. Ideally, the final decision should take into account functional results and cancer risks after the operation.

After the 90's, the introduction of RPC into the clinical practice and its indication in the face of the disease's clinical features led to a significant reduction of IRA. But one still recognizes that IRA is a technical procedure associated with low morbidity and good functional outcome, and its main indication lies on patients with rectal sparing polyps who agree with long term follow-up ${ }^{(19)}$. IRA is especially interesting in the attenuated form of the syndrome, where the rarity of rectal polyps allowed its indication in 9 from 12 patients with attenuated polyposis.

Nowadays, RPC is the most common procedure, as it eradicates the diseased colorectal mucosa and preserves the sphincter muscles, despite leading to greater operative morbidity ${ }^{(34)}$. In our patients, the impact of rectal dissection during surgery is clearly demonstrated by the complication rates after RPC (48.1\%), PCI (26.6\%) and IRA (19\%). The incidence of complications and their nature were comparable to some literature reports ${ }^{(4,23)}$, although others did not find differences regarding early or late complications and functional

TABLE 3. Clinical features of patients with rectal cuff recurrence

\begin{tabular}{|c|c|c|c|c|c|c|}
\hline Sex & M & $\mathrm{F}$ & $\mathrm{F}$ & M & M & $\mathbf{M}$ \\
\hline Initial age & 27 & 35 & 47 & 63 & 56 & 47 \\
\hline Interval & $48 \mathrm{mo}$ & $42 \mathrm{mo}$ & $132 \mathrm{mo}$ & $48 \mathrm{mo}$ & $34 \mathrm{mo}$ & $48 \mathrm{mo}$ \\
\hline Rectal polyps & present & present & present & present & present & present \\
\hline Colonic FAP & severe & severe & NS & severe & attenuated & attenuated \\
\hline Colonic cancer & present & present & present & present & present & absent \\
\hline Extra cancer & no & no & stomach & lymphoma & no & no \\
\hline Treatment & LR & PT & $\mathrm{PT}$ & LR & PT & NO \\
\hline Pathology & T1NOM0 & T3N0M0 & T2NOMO & T1N0M0 & T3NOM0 & M1 \\
\hline
\end{tabular}

$\mathrm{T}=\mathrm{mate} \mathrm{F}=$ female $; \mathrm{NF}=$ not stated data

$\mathrm{PT}=$ proctectomy $; \mathrm{LR}=$ local resection; $\mathrm{NO}=$ non operated $; \mathrm{mo}=$ months 
results between RPC and IRA ${ }^{(25)}$. This discordance is probably due to series with patients at varying ages and co-morbidities, as well as surgeons with different technical expertise.

In an interesting metanalysis, AZIZ et al.(2) compared 12 studies published from 1991 to 2003, reuniting 1,002 patients. The authors found less evacuatory dysfunction after IRA and a greater reoperation rate after RPC $(23.4 \%$ vs $11.6 \%)$. But there was no difference regarding sexual dysfunction or postoperative complications. Rectal cancer was diagnosed in $5.5 \%$ after IRA. Their conclusion was that both operations have their individual merits and that new studies are necessary to evaluate which technique provides more benefits to FAP patients.

One interesting perspective is the laparoscopic approach. Minimally invasive surgery results in less physiologic trauma, less adherences, shorter hospital stay and better cosmesis, although the long operative length is still an important disadvantage. In young patients with greater risks of reoperation, the benefits of laparoscopic resections are even more evident. But the indication of total colectomies is still limited and must be restricted to selected patients and skilled surgical teams ${ }^{(1,6,28)}$.

Surgical options for FAP oscillate between RPC morbidity and the supposed mortality due to rectal cancer after IRA that can happen despite careful follow-up ${ }^{(29)}$.

In the literature, the incidence of metachronous cancer in the rectal cuff varies from $12 \%$ to $43 \%{ }^{(14)}$. This variation may be attributed to colectomies in different extensions or surgical indication in different ages. This risk rises progressively with length of follow-up, reaching 5\%-12\% after 10 years ${ }^{26}$, 27), $23 \%$ after 15 years $^{(27)}$ and even $50 \%$ after 20 years from operation $^{(20,29)}$. Data from the Polyposis Registry in Sweden indicate a cumulative risk of $25.7 \%$ at 70 years of age ${ }^{(3)}$.

Today it is well known that this risk also depends on clinical factors such as age and rectal length, as well as pathological factors (presence of villous adenomas, displasia, number, size and shape of polyps) and molecular factors (mutation locus) $^{(18,24)}$.

Among our patients, there were detected rectal cuff cancer in six patients $(16.6 \%)$, whose average age was 45,8 years. This average age was significantly greater than that observed among patients who had undergone IRA and did not have rectal cuff recurrence (36,6 years, 17-82). Average time interval between colectomy and recurrence was 58,6 months.

All the patients had rectal polyps at initial operation or developed them during follow-up. Regarding the polyposis severity, only two patients had the attenuated form of the disease. These patients were 47 and 56 years old at operation, what suggests that age probably influenced this outcome. Five patients had colonic cancer in the surgical specimen. Treatment of such patients consisted of local resection (two), proctectomy (three) and one patients was not operated due to hepatic metastasis.

When possible, the indication of IRA in young patients (before 30 years) is more effective, allowing them to live at least 20 to 25 years in this situation without developing cancer in the reminiscent rectum ${ }^{(29)}$. And, although five of four patients had colonic cancer in the resected specimen, it is not known if this fact raises the chances of a future rectal cancer or if this is only related to the elevated age at the treatment.

The density of rectal polyps has been the most utilized criteria to choose the operative procedure in FAP patients, but the number is somewhat variable in the literature. It is important to note that the concept of a less severe colonic and rectal polyposis does not guarantee that a cancer will not develop in the future, as we attested in two of our patients with attenuated polyposis.

In this context, an interesting work ${ }^{(13)}$ reported that patients with less than five adenomas were frequently asymptomatic $(73 \%)$ and had a less severe polyposis in $86 \%$, allowing the performance of IRA $92.5 \%$ of them. In this group, only five patients $(6,9 \%)$ required proctectomy, none of them for cancer. On the other hand, those with more than 20 rectal adenomas required proctectomy in $35 \%$, four $(10.8 \%)$ for malignant degeneration. The authors concluded that proctoscopy was an effective method of preoperative selection, and that the presence of less than five rectal adenomas indicates a less aggressive disease associated with a good outcome after IRA. The results of this and other works ${ }^{(14)}$ lead us to adopt the same criteria to select the operative procedure, fact that increased the number of ileal pouches.

Another vision has come from the clinical and pathological data collected by VASEN et al. ${ }^{\left({ }^{36)}\right.}$, who reported the results of four National Polyposis Registries (Denmark, Finland, Sweden and Holland). In a group of 659 patients that had underwent IRA, 47 (7.1\%) developed rectal cancer and the risk of death due to rectal cancer was $12.5 \%$ at 65 years of age. When compared to IRA, there was an increased life expectancy of 1,8 years after RPC. Furthermore, $75 \%$ of the patients with rectal cancer had already had a normal rectoscopy 12 months before the diagnosis, showing that the follow-up does not provide effective protection against the development of rectal neoplasia.

The follow-up of operated patients shows that in a great proportion there is a spontaneous decrease of rectal polyps density after IRA, although this is a temporary phenomenon (3-4 years) ${ }^{(21)}$. While lesions smaller than $5 \mathrm{~mm}$ do not need to be excised, greater adenomas should be excised or cauterized. If occurs an increase in number $(>20)$, size $(>10 \mathrm{~mm})$ or displasia (to severe), one should excise all lesions greater than $5 \mathrm{~mm}$ and perform a new endoscopy after 6 months. If there is an eventual progression of these lesions, proctectomy should be considered.

In opposition to the occurrence of rectal cancer after IRA, RPC has been considered the operation of choice for FAP. It has been mainly indicated for adolescents, for those who cannot or refuse follow-up, for severe rectal polyposis and for cases of synchronous colon and upper rectum cancer ${ }^{(29)}$.

But the late rates of degeneration in the ileal pouch or at the anal transition zone (AZT) are still unknown. The development of pouch adenomas has been reported in variable incidences ranging from $4 \%$ to $50 \%$ of the cases ${ }^{(29,33)}$. Moreover, publications of adenocarcinoma cases ${ }^{(9,37)}$ suggest that the risk of malignization is not abolished. 
Different carcinogenic mechanisms were related to this risk, such as the presence of multiple pouch adenomas, their size, patient's age, incomplete mucosectomy and preservation of AZT. The confection of hand-sewn anastomosis with mucosectomy seems to reduce this risk as this procedure excludes residual rectal mucosa in the rectal cuff and at the anastomosis ${ }^{(32)}$. On the other hand, mucosectomy demands technical skills and residual islands of rectal mucosa have been found in $20 \%$ of resected pouches ${ }^{(30)}$.

Today, most of the pouches are performed using the double-stapled technique without mucosectomy, to preserve the AZT and to improve functional results. Besides this, the rectal epithelium forms digitations at the dentate line, predisposing the occurrence of displasia which requires local surveillance.

We have treated a patient with cancer after RPC, where a mucinous adenocarcinoma probably developed from residual mucosa between the ileal mucosa and the anal canal. Recent revisions about this subject showed that some cases developed after mucosectomy ${ }^{(9,16,37)}$, fact that clearly demonstrated that it is impossible to remove all the mucosa in practical terms.

The ideas we discussed here strenghten the recommendation for regular and long-term endoscopic surveillance of the pouches no matter what technique has been employed, till the natural history of polyps and the carcinogenic risk factors have been clarified.

Although there is no agreement to the frequency of examination, some authors suggest a 3-years interval when polyps are not detected in the pouch, 2-3 years when they are found and frequent follow-up in cases of advanced or numerous adenomas ${ }^{(33)}$.

Some data have to be considered to make a decision in each patient. Potential candidates for IRA are young patients with few polyps and no familiar history of severe disease, patients with attenuated disease and those who refuse the confection of a temporary ileostomy after ileal pouch ${ }^{(14,35)}$.

When deciding for IRA, surgeon and patient should recognize that regular examination may not necessarily detect eventual neoplasia in the rectal cuff, and that the risk of cancer increases with time, age and it is probably associated with previous colonic cancer. Familiar history or mutation related to severe polyposis should favor the indication of ileal pouch anastomosis.

Complications after RPC are common and morbidity rates are low, but not all surgeons obtain the same functional results with this procedure that also has consequences on female fertility ${ }^{(31)}$.

Another point is the ideal moment for the surgical treatment. In the context of the complexity of this genetic syndrome, the proper discussion of all the problems by a specialist is of sum importance to the patient's and family's acceptance. When available, the aid of genetic information (mutations related to severe polyposis or desmoid disease) may influence the final decision. Independently of the operation choice, the actual knowledge about the oncological outcome suggests regular surveillance after any kind of surgical procedure.

Campos FG, Perez RO, Imperiale AR, Seid VE, Nahas SC, Cecconello I. Tratamento cirúrgico da polipose adenomatosa familiar: anastomose íleo-retal ou bolsa ileal? Arq Gastroenterol. 2009;46(4):294-9.

RESUMO - Contexto - As controvérsias quanto a melhor forma de tratamento da polipose adenomatosa familiar confrontam a morbidade da proctocolectomia restauradora contra a suposta mortalidade decorrente de câncer retal após íleo-reto anastomose. Objetivos - Avaliar as complicações operatórias e a evolução oncológica dos pacientes submetidos a íleo-reto anastomose ou proctocolectomia restauradora. Métodos - Analisaram-se os dados dos doentes tratados entre 1977 e 2006, procedendo ao levantamento de dados clínicos gerais, endoscópicos, resultados do tratamento cirúrgico, dados anatomopatológicos e informações sobre a evolução precoce e tardia dos pacientes. Resultados - Foram tratados 88 pacientes, sendo 41 homens $(46,6 \%)$ e 47 mulheres $(53,4 \%)$. Por ocasião do diagnóstico, 53 pacientes $(60,2 \%)$ já tinham câncer colorretal associado à polipose. Registraram-se complicações operatórias em 25 doentes $(29,0 \%)$ dentre os 86 operados, sendo $17(19,7 \%)$ precoces e $8(9,3 \%)$ tardias. Houve mais complicações após proctocolectomia restauradora $(48,1 \%)$ em comparação às proctocolectomias com ileostomia $(26,6 \%)$ e íleo-reto anastomose $(19,0 \%)(P=0,03)$. Não houve mortalidade operatória. O risco cumulativo de câncer retal após íleo-reto anastomose foi de 17,2\% após 5 anos, 24,1\% após 10 anos e 43,1\% após 15 anos de seguimento pós-operatório. Já o risco cumulativo idade-dependente começou a existir a partir de 30 anos (4,3\%), passando para 9,6\% aos 40 anos, $20,9 \%$ aos 40 anos e $52 \%$ aos 60 anos. Entre os pacientes submetidos a bolsa ileal com seguimento (26), apenas 1 doente $(3,8 \%)$ desenvolveu câncer na bolsa ileal. Conclusões - 1. Ocorreram complicações operatórias em cerca de 1/3 dos pacientes, sendo mais frequentes após a confecção de bolsa ileal; 2. idade maior, tempo de seguimento e câncer colônico prévio se associaram ao desenvolvimento de câncer no coto retal após íleo-reto anastomose; 3. pacientes tratados por proctocolectomia restauradora não estão livres do risco de degeneração na bolsa ileal; 4. a complexidade da doença e a existência de diversos fatores de risco envolvidos (clínicos, endoscópicos, genéticos) indicam que a melhor decisão operatória seja baseada em características individuais a serem consideradas por um especialista; 5 . todos os pacientes operados requerem vigilância contínua e prolongada no seguimento pós-operatório.

DESCRITORES - Polipose adenomatosa do cólon. Pólipos adenomatosos. Neoplasias colorretais. Proctocolectomia restauradora. Anastomose cirúrgica. 


\section{REFERENCES}

1. Araújo SE, Nahas SC, Seid VE, Marchini GS, Torricelli FC. Laparoscopy-assisted ileal pouch-anal anastomosis: surgical outcomes after 10 cases. Surg Laparosc Endosc Percutan Tech. 2005;15:321-4.

2. Aziz O, Athanasiou T, Fazio VW, Nicholls RJ, Darzi AW, Church J, Phillips RK, Tekkis PP. Meta-analysis of observational studies of ileorectal versus ileal pouch-anal anastomosis for familial adenomatous polyposis. Br J Surg. 2006;93:407-17.

3. Bjork JA, Akerbrant HI, Iselius LE, Hultcrantz RW. Risk factors for rectal cancer morbidity and mortality in patients with familial adenomatous polyposis after colectomy and ileorectal anastomosis. Dis Colon Rectum. 2000;43: 1719-25.

4. Bjork J, Akerbrant H, Iselius L, Svenberg T, Oresland T, Pahlman L, Hultcrantz R. Outcome of primary and secondary ileal pouch-anal anastomosis and ileorectal anastomosis in patients with familial adenomatous polyposis. Dis Colon Rectum. 2001;44:984-92.

5. Campos FG. Considerações técnicas e resultados iniciais das colectomias totais por vídeo-laparoscopia. Existem vantagens? Rev Bras Coloproctol. 2004;24:179-85.

6. Campos FG. Polipose adenomatosa familiar. Características clínicas e resultados do tratamento cirúrgico [tese]. São Paulo: Faculdade de Medicina da Universidade de São Paulo; 2006.

7. Campos FG, Habr-Gama A. Síndromes polipóides do intestino grosso. In: Fderação Brasileira de Gastroenterologia. Condutas em gastroenterologia. São Paulo: Revinter; 2004. p.262-78.

8. Campos FG, Habr-Gama A. Polipose adenomatosa familiar. In: Moraes IN, editor. Tratado de clínica cirúrgica. São Paulo: Roca; 2005. p.1406-415.

9. Campos FG, Habr-Gama A, Kiss DR, Atui FC, Katayama F, Gama-Rodrigues J. Extracolonic manifestations of familial adenomatous polyposis: incidence and impact on the disease outcome. Arq Gastroenterol. 2003;40:92-8.

10. Campos FG, Habr-Gama A, Kiss DR, da Silva EV, Rawet V, Imperiale AR, Perez R, da Silva JH, Sousa AH Jr, Gama-Rodrigues J. Adenocarcinoma after ileoanal anastomosis for familial adenomatous polyposis: review of risk factors and current surveillance apropos of a case. J Gastrointest Surg. 2005;9:695-702.

11. Church JM. Anatomy of a gene: functional correlations of APC mutation. Semin Colon Rectum Surg. 1998;9:49-52.

12. Church J. Ileoanal pouch neoplasia in familial adenomatous polyposis: an underestimated threat. Dis Colon Rectum. 2005;48:1708-13.

13. Church J, Burke C, McGannon E, Pastean O, Clark B. Predicting polyposis severity by proctoscopy: how reliable is it? Dis Colon Rectum. 2001;44:1249-54.

14. Church JM, McGannon E, Burke C, Clark B. Teenagers with familia adenomatous polyposis: what is their risk for colorectal cancer? Dis Colon Rectum. 2002;45:887-9.

15. Church J, Burke C, McGannon E, Pastean O, Clark B. Risk of rectal cancer in patients after colectomy and ileorectal anastomosis for familial adenomatous polyposis: a function of available surgical options. Dis Colon Rectum. 2003;46:1175-81.

16. Church J, Simmang C. Practice parameters for the treatment of patients with dominantly inherited colorectal cancer (familial adenomatous polyposis and hereditary nonpolyposis colorectal cancer). Dis Colon Rectum. 2003;46:1001-12.

17. Croner RS, Brueckl WM, Reingruber B, Hohenberger W, Guenther K. Age and manifestation related symptoms in familial adenomatous polyposis. BMC Cancer. 2005;5:24

18. Debinski HS, Love S, Spigelman AD, Phillips RK. Colorectal polyp counts and cancer risk in familial adenomatous polyposis. Gastroenterology. 1996;110:1028-30.

19. Eu KW, Lim SL, Seow-Choen F, Leong AF, Ho YH. Clinical outcome and bowel function following total abdominal colectomy and ileorectal anastomosis in the oriental population. Dis Colon Rectum. 1998;41:215-8.

20. Farmer KCR, Phillips RKS. Colectomy with ileorectal anastomosis lowers rectal mucosal cell proliferation in familial adenomatous polyposis. Dis Colon Rectum. 1993;36:167-71.
21. Feinberg SM, Jagelman DG, Sarre RG, McGannon E, Fazio VW, Lavery IC, Weakley FL, Easley KA. Spontaneous resolution of rectal polyps in patients with familial polyposis following abdominal colectomy and ileorectal anastomosis. Dis Colon Rectum. 1988;31:169-75.

22. Giardiello FM, Brensinger JD, Petersen GM, Luce MC, Hylind LM, Bacon JA Booker SV, Hamilton SR. The use and interpretation of commercial APC gene testing for familial adenomatous polyposis. N Engl J Med. 1997;336:823-7.

23. Gunther K, Braunrieder G, Bittorf BR, Hohenberger W, Matzel KE. Patients with familial adenomatous polyposis experience better bowel function and quality of life after ileorectal anastomosis than after ileoanal pouch. Colorectal Dis. 2003;5:38-44.

24. Gurbuz AK, Giardiello FM, Petersen GM, Krush AJ, Offerhaus GJA, Booke SV, Kerr MC, Hamilton SR. Desmoid tumors in familial adenomatous polyposis. Gut. 1994;35;377-81.

25. Hassan I, Chua HK, Wolff BG, Donnelly SF, Dozois RR, Larson DR, Schleck $\mathrm{CD}$, Nelson H. Quality of life after ileal pouch-anal anastomosis and ileorectal anastomosis in patients with familial adenomatous polyposis. Dis Colon Rectum. 2005;48:2032-7.

26. Heimann TM, Greenstein AJ, Bolnick K, Yoelson S, Aufses AH Jr. Colorecta cancer in familial polyposis coli and ulcerative colitis. Dis Colon Rectum. $1985 ; 28: 658-61$

27. Iwama T, Tamura K, Morita T, Hirai T, Hasegawa H, Koizumi K, Shirouzu K, Sugihara K, Yamamura T, Muto T, Utsunomiya J. A clinical overview of familial adenomatous polyposis derived from the database of the Polyposis Registry of Japan. Int J Clin Oncol. 2004;9:308-16.

28. Milsom JW, Ludwig KA, Church JM, Garcia-Ruiz A. Laparoscopic total abdominal colectomy with ileorectal anastomosis for familial adenomatous polyposis. Dis Colon Rectum. 1997;40:675-8.

29. Nugent KP, Spigelman AD, Phillips RKS. Life expectancy after colectomy and ileorectal anastomosis for familial adenomatous polyposis. Dis Colon Rectum. 1993;36:1059-62

30. O'Connell PR, Williams NS. Mucosectomy in restorative proctocolectomy. $\mathrm{Br}$ J Surg. 1991;8:129-30.

31. Olsen KØ, Juul S, Bülow S, Järvinen HJ, Bakka A, Björk J, Oresland T, Laurberg S. Female fecundity before and after operation for familial adenomatous polyposis. Br J Surg. 2003;90:227-31.

32. Slors JF, Ponson AE, Taat CW, Bosma A. Risk of residual rectal mucosa after proctocolectomy and ileal pouch-anal reconstuction with the double-stapling technique: postoperative endoscopic follow-up study. Dis Colon Rectum. 1995;38:207-10.

33. Thompson-Fawcett MW, Marcus VA, Redston M, Cohen Z, McLeod RS Adenomatous polyps develop commonly in the ileal pouch of patients with familial adenomatous polyposis. Dis Colon Rectum. 2001;44:347-53.

34. Tonelli F, Valanzano R, Monaci I, Mazzoni P, Anasti A, Ficari F. Restorative proctocolectomy or rectum-preserving surgery in patients with familial adenomatous polyposis: results of a prospective study. World J Surg. 1997;21:653-9.

35. Valanzano R, Ficari F, Curia MC, Aceto G, Veschi S, Cama A, Battista P, Tonell F. Balance between endoscopic and genetic information in the choice of ileorecta anastomosis for familial adenomatous polyposis. J Surg Oncol. 2007:95:28-33.

36. Vasen HF, van Duijvendijk P, Buskens E, Bulow C, Bjork J, Jarvinen HJ, Bulow S Decision analysis in the surgical treatment of patients with familial adenomatous polyposis: a Dutch-Scandinavian collaborative study including 659 patients. Gut. 2001;49:231-5

37. Vogel JD, Church JM. Post-operative endoscopic surveillance of rectal pouch following total abdominal colectomy with ileorectal anastomosis (IRA) and total proctocolectomy with ileal pouch anal anastomosis (IPAA) in familia adenomatous polyposis and hereditary nonpolyposis colorectal cancer. Tech Gastrointest Endosc. 2006:8:114-8.

38. Wu JS, Paul P, McGannon EA, Church JM. APC genotype, polyp number and surgical options in familial adenomatous polyposis. Ann Surg. 1998;227:57-62.

Recebido em 2/3/2009

Aprovado em 29/4/2009. 